\title{
Evaluation of the Impacts of the Climate Changes on the Hydrological Network of the Kouilou-Niari Basin in the South-West of Congo Brazzaville
}

\author{
Christian Ngoma Mvoundou ${ }^{1}$, Christian Tathy ${ }^{1,2}$, Dominique Nkounkou Tomodiatounga ${ }^{1}$, \\ Raymond Gentil Elenga $^{1,3}$, Guy Moukandi Nkaya ${ }^{1}$, Bernard Mabiala ${ }^{1, *}$ \\ ${ }^{1}$ Laboratory of Mechanics Energy and Engineering, Higher National Polytechnic School, Marien Ngouabi University, Brazzaville, Congo \\ ${ }^{2}$ Department of Exact Sciences, Higher Teacher's Training School, Marien Ngouabi University, Brazzaville, Congo \\ ${ }^{3}$ Department of Physic, Faculty of Sciences and Technics, Marien Ngouabi University, Brazzaville, Congo
}

Email address:

bernamab@hotmail.com(B. Mabiala)

${ }^{*}$ Corresponding author

\section{To cite this article:}

Christian Ngoma Mvoundou, Christian Tathy, Dominique Nkounkou Tomodiatounga, Raymond Gentil Elenga, Guy Moukandi Nkaya, Bernard Mabiala. Evaluation of the Impacts of the Climate Changes on the Hydrological Network of the Kouilou-Niari Basin in the SouthWest of Congo Brazzaville. Journal of Water Resources and Ocean Science. Vol. 7, No. 3, 2018, pp. 28-41. doi: 10.11648/j.wros.20180703.12

Received: June 6, 2018; Accepted: July 31, 2018; Published: August 22, 2018

\begin{abstract}
The study of the rainfall-runoff relation on annual and monthly scales is based on the hydrological data measured in various stations of the Kouilou-Niari basin. The parameters of the rainfall-runoff modeling were obtained with satisfaction by today's standards of quality. The objective of this study is to evaluate the impacts of the climate changes on the water resources of the catchment area of Kouilou-Niari using hydrological modeling. With this intention, a sample of twelvestations was selected on a hydrological cycle of more than thirty years (1952-1982). The results obtained show that the variations of the flows follow those of precipitation: reduction in N'douo zone and Niarizone and increase in Kouilou zone. These stations present a bimodal mode, with a double maximum during the rainyseasons (MAM and OND). Season (MAM) is themost rainy and season (JJAS) is the least rainy in all the stations. The relation between rainfalls and runoffs is satisfactory, because the hydrological mode models itselfonprecipitation one. The flows of the basin are rising, with anaveragestreamflow of 445 $\mathrm{m}^{3} /$ sincluded between a minimum of $86.2 \mathrm{~m}^{3} / \mathrm{s}$ and a maximum of $930.4 \mathrm{~m}^{3} / \mathrm{s}$ for respective specific modules of 16.91 and $23.731 . \mathrm{s}^{-1} / \mathrm{km}^{2}$. The return periods of the floods are estimated of 5,10 and 50 years for respective streamflows of 2470,2620 and $2682 \mathrm{~m}^{3} / \mathrm{s}$. This particular behavior of the basin finds its reasons not only in the pluviometric mode but also in the physical characteristics (relief, geologyand pedology). The Kecoefficient of flow is $42.9 \%$ and the seasonal variation $\mathrm{K} 3$ is 13.3 atSounda station.
\end{abstract}

Keywords: Kouilou-Niari Basin, Climate Change, Hydrological Network, Hydrological Data

\section{Introduction}

Taking into account the impacts of the climate change on the hydrological resources in a catchment aera and sometimes its dramatic consequences, the evolution of water resources becomes a major concern for many countries inthe world [1-8]. This is all the more true for the african countries, particularly those of the sahelianzone, subjected since more than one half-century, with a persistent dryness [9-10]. The question of the climate change is nowadays, a planetary issue, as it is attested by the publication of the third report of the intergovernmental group of experts on the evolution of the climate [11]. But if knowledgeson the evolution of the climate and the role of the gas emissions for greenhouse effectspurposesnever cease to improve, much questions will persist such as the incidences of the climate change on the anthropic and natural systems.

Based on the use of the climatic variables produced by the hydrological models, this study presents the impacts of the 
climate change on the flows of the Kouilou-Niari basin and makes it possible to quantify the phenomena of extreme type like the exceptional floodin this basin. The dryness knew no equivalent, neither in duration, nor in intensity, on the whole of the studied period. A statistical study, certified by charts of these various periods, however highlights the strongly heterogeneous character of the phenomenon in space [12-14]. This work, which relates to the evaluation of the impacts of the climate change on the hydrological network of the Kouilou-Niari basin, is a contribution on the understanding of the operation of the climatological elements of this basin on a hydrological cycle of more than 30 years (1952-1982). The main objective of this study being to make a hydrological assessment of the flows of the main stations installed all along thisbasin.

\section{Materials and Methods}

\subsection{Materials}

\subsubsection{Zone of Study}

The study concerns to a hydrographic unit located at the south-west of the Republic of Congo (Figure 1). The catchment area of Kouilou-Niarimeasures $690 \mathrm{~km}$ in length with anaveragestreamflow of more than $930 \mathrm{~m}^{3} / \mathrm{s}$ and a surface area of $60000 \mathrm{~km}^{2}$ approximately. Its hydrological mode corresponds to the wet tropical mode with long periods of high waters, still called bimodal mode.

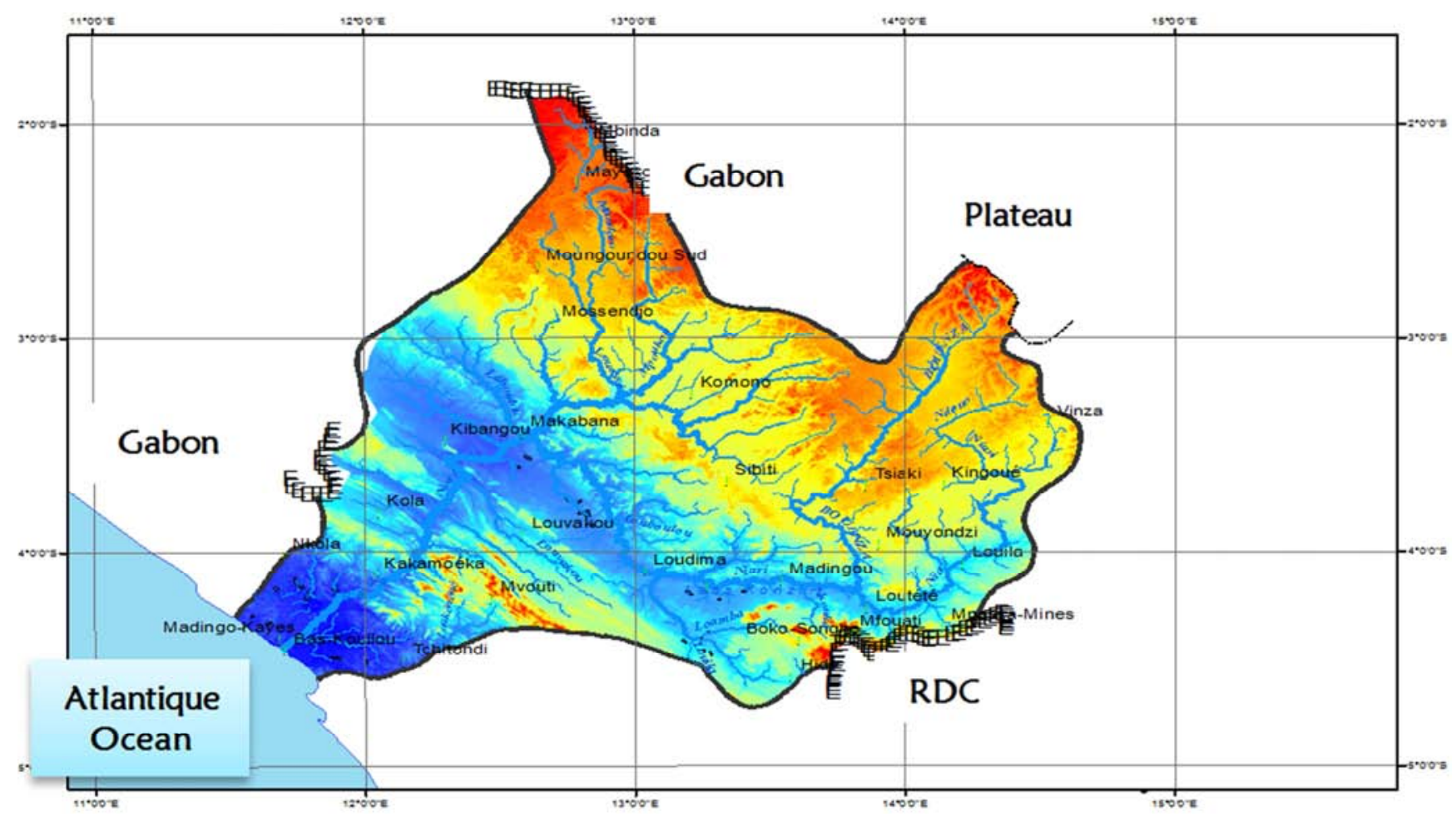

Figure 1. Chart of the localization of the zone of study.

The cross profile of the Kouilou-Niari basinleaves fromMoukomo station in N'douo zone (altitude $\mathrm{Z}=600 \mathrm{~m}$ ) to Madingokayesin Kouilou zone (altitude $\mathrm{Z}=0 \mathrm{~m}$ ), (Figure 2).

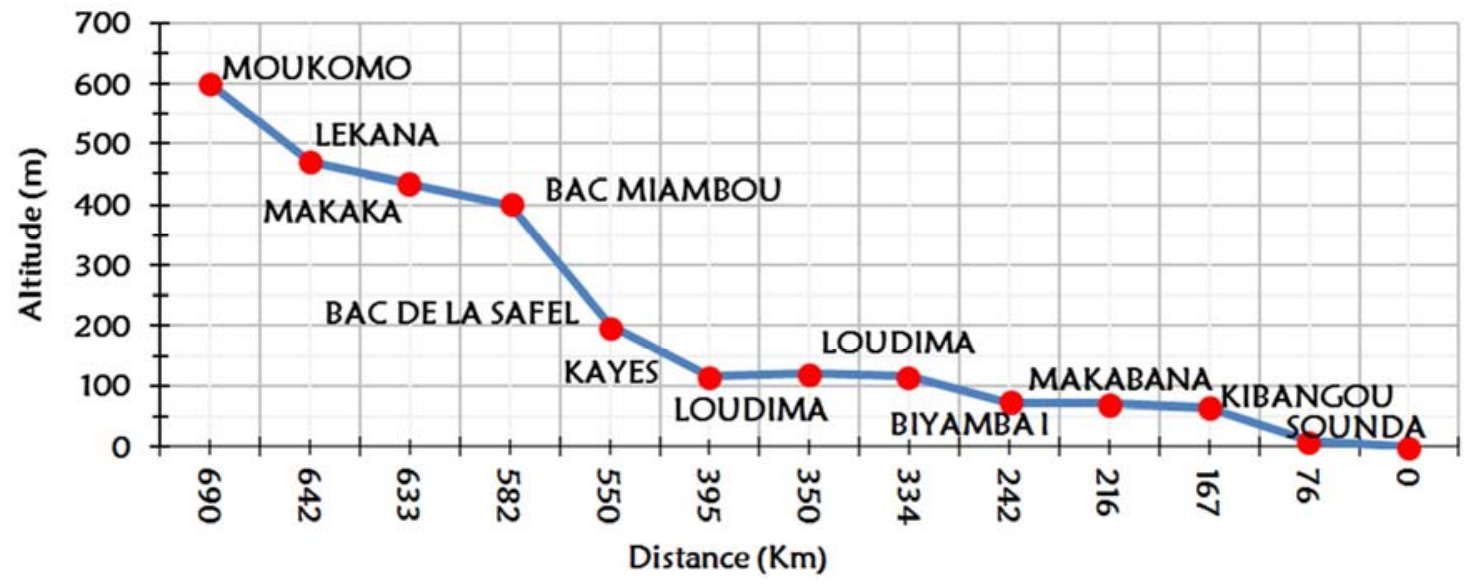

Figure 2. Cross profile of the river KouilouNiari. 
The geology of the Kouilou-Niari basin is related on the type of the soil and the importance of precipitation. All the Northern of the basin has a crystalline soil and with a lot of rainfall, and is covered by the equatorial forest. This strong plant cover contributes strongly to deaden the floods. The massif of Mayombe is also covered by the forest. The soil of the basin is impermeable, such a plant cover obstructvery little the runoff, and thefloods can be very violents. The geology is primarily consisted of the schistolimestoneformations of the superior Precambrian, of marlylimestones of Bouenza and Batéké sand. It is covered with anargilo-sandy soil to sandy-clayey, with average permeability in general. The hydrographic network is clear and very dense.

Forest vegetation reduces runoff on this much rainy part of the basin. The sedimentary soils occupy the centraland southern part of the basin. On the limestone formations, are superimposed more recent rocks: arkose micaceous, often reddish, belonging to the series known as schisto-sandy. They are sometimes surmounted by sablo-argillaceous ferraliticsoils with argilo-sandy, in general not very permeable, producing a runoff. The large variety of the rocks of the basin involves very significant variations in the mode of the various rivers constituting Kouilou-Niari. This influence is all the stronger as, in the equatorial mode where rainfalls are relatively concentratedin time, runoff is particularly sensitive to the geological nature of the soil [15].

The zone of study belongs to the wet tropical field and extends on different microclimates going from the area of savannas in north to the zone of forest in the south of the basin. The more or less great abundance of precipitation and their seasonal distributions constitute the characteristics determining various climatic zones. Indeed, rainfall is the most dominant climatic parameter which, so it is used for the definition of the climatic modes [16]. There arefourclimatic periods in the basin of Kouilou-Niari, distributed as follows: small dry season, januaryandfebruary (JF); great rainy season, march tomay (MAM); great dry season, junetoseptember (JJAS); small rainy season, octobertodecember (OND).

\subsubsection{Hydroclimatological Data}

The hydrological data are primarily of monthly time step and have been obtained from the meteorological services of the National Agency of Civil Aviation (A.N.A.C) at Brazzaville and other sources. The received and treated data are those availablesfor the period of 1952 to 1982 corresponding with a 30 years hydrological cycle.The rainfall data with monthlytime step and hydrometric data covering the hydrological period of 1952 to 1982 , have been obtained from the hydrometric stations of the Kouilou-Niari basin managed by the hydrological service of the ORSTOM. In thezone of study, the monthly distribution of precipitation is bimodal, with two maxima which occur in december for the first and in april for the second and for which the proportions fluctuate between 70 and $90 \%$ of the total annual. The flows of the Kouilou-Niari basin increase in north-south direction while precipitation make the opposite, with a streamflows ranging between 86.2 and $930.4 \mathrm{~m}^{3} / \mathrm{s}$ with an average of $425.6 \mathrm{~m}^{3} / \mathrm{s}$, its specific module is 23.73 $1 / \mathrm{s} / \mathrm{km}^{2}$ atSoundastation on Kouilou river.

The Kouilou-Niari basin suffers differently the factors of the climate which are the air temperature, the air relative humidity, the winds, etc. This irregular and changeable distribution of these parameters is at the origin of the diversity of the climates. For that, the geographical disparities and shifts which moderate the regularity of the climates must be added [17]:

a. Temperature: in all the basin, the highest temperatures are reached in march, during the rainy season, with the maximum ones of $33^{\circ} \mathrm{C}$ and minima of $23^{\circ} \mathrm{C}$ on the dayly scale.

b. Relative Humidity: like the temperature, the air relative humidity is high everywhere, it is higher than $85 \%$ in the zones of forest and than $80 \%$ elsewhere. It has a weak seasonal variation from 10 to $13 \%$. The maximum is reached in rainy season and the minimum in dry season. Its dayly variation is very marked.

c. Insolation: the annual average insolation hardly exceeds 2000 hours in all the country (approximately 1900 hours in Brazzaville and 1600 hours in Pointe-Noire). It is weak because of the strong nebulosity. The diffuse radiation is always raised and contributes in a proportion of $60 \%$ of the total radiation estimated of 540 calories per $\mathrm{cm}^{2}$ per day [12].

d. Evaporation: the evapotranspirations calculated using Penman method lie on average between 1100 and 1300 $\mathrm{mm}$ per year. They never reached $1400 \mathrm{~mm}$ per year [13].

\subsection{Methods of Hydrological Modeling}

The method used to evaluate the impacts of the climate change on the hydrological network of the catchment area of Kouilou-Niari, is subdivided in three stages: (i) hydroclimaticdata gathering, they come from two sources (climatological and hydrometric). 12 climatological stations were retained over period 1952-1982; (ii) processing of data received from the various stations during the hydrological cycle, usingsome mathematical expressions and (iii) hydrological modeling by doing a hydrological balance of the catchment area. These data were subjected to the various traditional statistical analyses (average, standard deviation, coefficient of variation, etc). These analyses make it possible to characterize the rainfall and hydrological aspects of basin.

The statistical methods used for this study were largely described in many papers [18-26]. Hydrological modeling with monthly timestep of the Kouilou-Niari basin was possible by using the following mathematical expressions, applied to a data serie $X=\left(X_{i}\right)_{1 \leq i \leq N}$ :

Arithmetic average:

$$
\overline{\mathrm{X}}=\frac{1}{\mathrm{~N}} \sum_{\mathrm{i}=1}^{\mathrm{N}} \mathrm{X}_{\mathrm{i}}=\mathrm{m}_{1}(\mathrm{X})
$$


Moving average over three (3) years:

$$
\overline{\mathrm{X}_{\mathrm{m}}}=\frac{1}{3} \sum_{\mathrm{i}=0}^{2} \mathrm{X}_{\mathrm{i}+\mathrm{m}} \text { with } 1 \leq m \leq N-2
$$

Standard deviation:

$$
\sigma=\sqrt{\frac{1}{n} \sum_{i=1}^{N}\left(X_{i}-\bar{X}\right)^{2}}
$$

Coefficient of variation:

$$
\mathrm{Cv}=\frac{\sigma}{\overline{\mathrm{X}}}
$$

Monthly coefficient of flow;

$$
\mathrm{C}_{\mathrm{m}}(\%)=\frac{\overline{\mathrm{Q}}_{\mathrm{m}}}{\sum_{\mathrm{i}=\mathrm{Jan}}^{\mathrm{Dec}} \overline{\mathrm{Q}}_{\mathrm{m}}} \text { withJan } \leq m \leq \text { Dec }
$$

Anomaly (Centered reduced or standardized data):

$$
\Delta \mathrm{x}=\frac{\left(\mathrm{X}_{\mathrm{i}}-\overline{\mathrm{X}}\right)}{\sigma}
$$

Equivalent water:

$$
\text { Le }=\frac{Q}{S} \times 31,5
$$

Draining water:

$$
\mathrm{He}=\frac{\mathrm{Q}}{\mathrm{S}} \times 86,4 \times 365
$$

Coefficient of flow:

$$
\mathrm{Ke}=\frac{\mathrm{He}}{\mathrm{HP}} \times 100
$$

Index of irregularity (K3) or Coefficient of seasonal variation:

$$
\mathrm{K} 3=\frac{\mathrm{Q}_{\operatorname{maxi}}}{\mathrm{Q}_{\operatorname{mini}}}
$$

Deficitof flow:

$$
\mathrm{De}=\mathrm{HP}-\mathrm{He}
$$

Straight regression line of the rainfall-runoff correlation:

$$
\mathrm{Y}=\mathrm{ax}+\mathrm{b}
$$

Hydraulicity:

$$
\mathrm{Ec}=\frac{\left[\mathrm{Q}_{\max }-\mathrm{Q}_{\operatorname{mini}}\right]}{\mathrm{Q}_{\operatorname{mini}}} \times 100
$$

Hydroclimatology:

$$
\mathrm{Hyc}=\frac{\left[\overline{\mathrm{Q}}_{\mathrm{i}}-\overline{\mathrm{Q}}\right]}{\overline{\mathrm{Q}}} \times 100
$$

Return period of floods:

$$
\mathrm{T}=\frac{1}{\mathrm{~F}}
$$

In this expressions $Q$ is the streamflow $\left(\mathrm{m}^{3} / \mathrm{s}\right), \mathrm{F}$ is frequency, $\mathrm{S}$ is surface area $\left(\mathrm{km}^{2}\right), \mathrm{HP}$ is average precipitation (mm), $\overline{\mathrm{Q}}_{\mathrm{mth}}$ is interannual average streamflow of mth month, $\overline{\bar{Q}}_{\mathrm{i}}$ is the average of year $\mathrm{I}$ and $\mathrm{a}$ and $\mathrm{b}$ are constant coefficients.

\section{Results}

\begin{tabular}{|c|c|c|c|c|c|c|c|c|c|}
\hline \multirow{2}{*}{ Basin } & \multirow{2}{*}{ Under-basin } & \multirow{2}{*}{ River } & \multirow{2}{*}{ Station } & \multicolumn{4}{|c|}{ Interannual streamflow in $\mathrm{m}^{3} / \mathrm{s}$} & \multirow{2}{*}{$\begin{array}{l}\text { Standard } \\
\text { deviation }\end{array}$} & \multirow{2}{*}{$\begin{array}{l}\mathrm{Cv} \\
(\%)\end{array}$} \\
\hline & & & & $\operatorname{Max}$ & Min & Median & Average & & \\
\hline \multirow{12}{*}{$\begin{array}{l}\text { Kouilo } \\
\text { u-Niari }\end{array}$} & \multirow{2}{*}{$\begin{array}{l}\text { Upper course } \\
\text { (n'douo) }\end{array}$} & N'douo & Moukomo & 230 & 26 & 128 & 80.2 & 32.3 & 40.2 \\
\hline & & Mpoukou & Lekana & 200 & 33 & 117 & 92.2 & 35.9 & 38.9 \\
\hline & \multirow{9}{*}{$\begin{array}{l}\text { Middle course } \\
\text { (niari) }\end{array}$} & \multirow{2}{*}{ Bouenza } & Makaka & 230 & 43 & 136 & 100.6 & 35.5 & 35.3 \\
\hline & & & Bac miambou & 730 & 40 & 385 & 108.6 & 37.9 & 34.9 \\
\hline & & \multirow{4}{*}{ Niari } & Kibangou & 2397 & 115 & 1256 & 846.8 & 387.5 & 45.8 \\
\hline & & & Kayes & 945 & 82 & 514 & 332.3 & 160.8 & 48.4 \\
\hline & & & Loudima & 994 & 89 & 542 & 345.8 & 162.8 & 47.1 \\
\hline & & & Bac safel & 475 & 33 & 254 & 170.1 & 90.9 & 53.4 \\
\hline & & Loudima & Loudima & 113 & 8 & 61 & 385.3 & 186.7 & 48.5 \\
\hline & & \multirow{2}{*}{ Louéssé } & Biyamba 1 & 146 & 7 & 77 & 59.5 & 25.7 & 43.3 \\
\hline & & & Makabana & 763 & 73 & 418 & 306.1 & 125.7 & 41.1 \\
\hline & Lower course (kouilou) & Kouilou & Sounda & 2682 & 201 & 1442 & 930.4 & 438.4 & 47.1 \\
\hline \multicolumn{4}{|c|}{ Kouilou-Niari Basin } & 1104 & 102 & 603 & 421 & 192.32 & 45.71 \\
\hline
\end{tabular}

The analysis and the interpretation of the climatological results of the flows of the basin and of the main hydrological stations, by means of the charts in order to better evaluate the impacts of the climate change on the hydrological network of the catchment area of Kouilou-Niari, were possible by dividing the basin into three hydrological zones gathering the 12 main stations of the basin: upper course (N'douo zone), middle Course (Niari zone) and lower course (Kouilou zone). Generally, the hydrological modes of the rivers of the basin are closely related to the rainfall modes. The interannualstreamflows are very close from one station to another (Table 1).

Table 1. Interannualstreamflows of the Kouilou-Niari Basin (1952-1982). 


\subsection{Annual Evolution of the Flows}

\subsubsection{Hydraulicity}

The evolution of the annual hydraulicities of the KouilouNiari basin (Figure 3), by using the formula (13), shows a downward trend and an upward trend respectively which are the results of the periods in deficit and of the periods insurplus. Thisevolution of the flows is similar to that of precipitation. These hydraulicities are characterized by a significant differences between the least rainy years, whose values are in deficitand the most rainy ones, whose values are in surplus. Comparing them with those of the neighbourDjoué river $(0.8$ and 1.2), the Kouilou-Niari basin has strong hydraulicities ranging between 2.5 and 5.54 with a maximum streamflow of $2682 \mathrm{~m}^{3} / \mathrm{s}$ in May 1953 at Soundastation representing the exceptional flood and an exceptional humidity and a minimal streamflow of $7.3 \mathrm{~m}^{3} / \mathrm{s}$ in Mars 1978 atBiyambalstation qualified of exceptional low water.
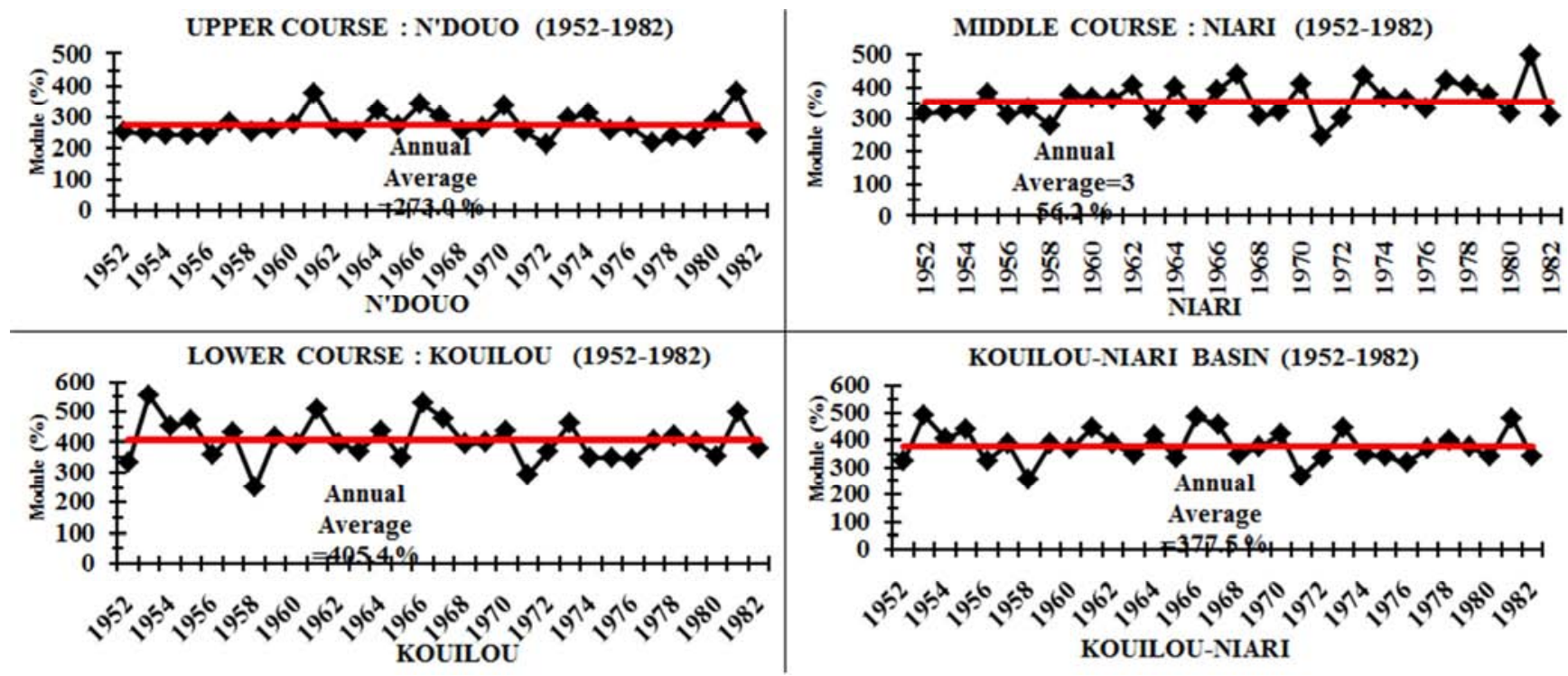

Figure 3. Evolution of Hydraulicity (13) in the three courses of the Kouilou-Niari Basin.

\subsubsection{Hydroclimatologicalvariability}

The evolution of the annual flows (1952-1982), on the whole of the Kouilou-Niari basin, presents an alternation of the deficit and surplus years (Figure 4). It is thus possible to define the years for which the hydraulicity is upper or lower than the average. These evolutions are linked to the rainfall variations with dry and wet years. In the whole of the basin, the various dry and wet periods were obtained by the method of the variations of the streamflows, by using the formula (14). 8 classes of streamflows were obtained according to the percentage of humidity [27]. The limit values of the classes of the streamflows corresponding to the percentages of humidityare divided in 8 classes (Table 2).

Table 2. Classification of streamflows [27].

\begin{tabular}{llll}
\hline $\mathbf{N}^{\circ}$ & Classifystreamflows & Rate & Observation \\
\hline 1 & Exceptionallywet & $60 \%<\mathrm{EH} / \mathrm{ES} \leq 100 \%$ & $\mathrm{EH}$ \\
2 & Exceptionally dry & & $\mathrm{ES}$ \\
3 & Verywet & $40 \%<\mathrm{TH} / \mathrm{TS} \leq 60 \%$ & $\mathrm{TH}$ \\
4 & Very dry & $20 \%<\mathrm{MH} / \mathrm{MS} \leq 40 \%$ & $\mathrm{TS}$ \\
5 & Fairlywet & & $\mathrm{MH}$ \\
6 & Fairlydry & $0 \%<\mathrm{H} / \mathrm{S} \leq 20 \%$ & $\mathrm{MS}$ \\
7 & Wet & $\mathrm{H}$ & $\mathrm{S}$ \\
8 & Dry & & \\
\hline
\end{tabular}

The fluctuations of the flows of the various rivers of the basin, show that during the period 1952-1982, the KouilouNiari basin knew an alternation of 14 wet years and 17 dry years, not exceeding 3 consecutive years (Figure 4). The analysis of the results shows that at the beginning of the years 1960 to 1965 , all the rivers knew one wet period (Table 3 ). But, that lasted only 14 years for NDouo zone, 18 years for Niari zone and 15 years for Kouilou zone. In the whole of the basin, this phenomenon lasted only 14 years. The rest of the years are known as dry. The results show that the basin knew remarkable years such as, the years 1952, 1960, 1964, 1965, 1973 and 1977 known as wet in all the courses of the basin and conversely the years 1954, 1959, 1968, 1969, 1976 and 1982 known as dry (Table 3). 
Table 3. Classifications of streamflowsrelatively to years in the Kouilou-Niari basin.

\begin{tabular}{|c|c|c|c|c|c|c|}
\hline \multirow{3}{*}{\multicolumn{2}{|c|}{ Hydrologicalentity }} & & \multicolumn{4}{|c|}{ Hydrological Classification } \\
\hline & & & \multicolumn{2}{|l|}{ Under-Basin } & \multicolumn{2}{|l|}{ Basin } \\
\hline & & & Upper Course (N'douo) & Middle Course (Niari) & Lower Course (Kouilou) & Kouilou-Niari \\
\hline \multirow{8}{*}{$\begin{array}{l}\text { Classes of } \\
\text { streamflows }\end{array}$} & \multirow[b]{4}{*}{ Humidperiods } & $\mathrm{EH}$ & & & 1961 & \\
\hline & & $\mathrm{TH}$ & & 1961 & & 1961 \\
\hline & & $\mathrm{MH}$ & 1961-1962 & 1966 & 1953-1955-1962-1966-1970 & 1953-1962-1966 \\
\hline & & $\mathrm{H}$ & $\begin{array}{l}1952-1956-1960-1964- \\
1965-1966-1970-1973- \\
1977-1979-1980-1981\end{array}$ & $\begin{array}{l}1952-1953-1955-1957- \\
1960-1962-1964-1965- \\
1967-1970-1973-1974- \\
1975-1977-1980-1981\end{array}$ & $\begin{array}{l}\text { 1952-1957-1960-1963-1964- } \\
1965-1967-1973-1977\end{array}$ & $\begin{array}{l}1952-1955-1957-1960- \\
1964-1965-1967-1970- \\
1973-1977\end{array}$ \\
\hline & \multirow[b]{4}{*}{ DryPeriods } & ES & & & & \\
\hline & & TS & & & $1958-1978$ & 1958 \\
\hline & & MS & 1978 & $1958-1978$ & $1971-1972$ & $1972-1978$ \\
\hline & & $\mathrm{S}$ & $\begin{array}{l}1953-1954-1955-1957- \\
1958-1959-1963-1967- \\
1968-1969-1971-1972- \\
1974-1975-1976-1982\end{array}$ & $\begin{array}{l}1954-1956-1959-1963- \\
1968-1969-1971-1972- \\
1976-1979-1982\end{array}$ & $\begin{array}{l}\text { 1954-1956-1959-1968-1969- } \\
1974-1975-1976-1979-1980- \\
1981-1982\end{array}$ & $\begin{array}{l}1954-1956-1959-1963- \\
1968-1969-1971-1974- \\
1975-1976-1979-1980- \\
1981-1982\end{array}$ \\
\hline
\end{tabular}

Table 3. Continue.

\begin{tabular}{|c|c|c|c|c|c|c|}
\hline \multirow{3}{*}{\multicolumn{2}{|c|}{ Hydrologicalentity }} & & \multicolumn{4}{|c|}{ Results / synthesis of the hydrological cycle } \\
\hline & & & \multicolumn{4}{|c|}{ Frequency of the events } \\
\hline & & & Upper Course (N'douo) & Middle Course (Niari) & Lower Course (Kouilou) & Bassin Kouilou-Niari \\
\hline \multirow{7}{*}{$\begin{array}{l}\text { Classes of } \\
\text { streamflows }\end{array}$} & \multirow{5}{*}{ Humidperiods } & $\mathrm{EH}$ & & & 1 & \\
\hline & & $\mathrm{TH}$ & & 1 & & 1 \\
\hline & & MH & 2 & 1 & 5 & 3 \\
\hline & & $\mathrm{H}$ & 12 & 16 & 9 & 10 \\
\hline & & ES & & & & \\
\hline & \multirow{2}{*}{ DryPeriods } & MS & 1 & 2 & 2 & 2 \\
\hline & & $\mathrm{S}$ & 16 & 11 & 12 & 14 \\
\hline \multicolumn{3}{|c|}{$\begin{array}{l}\text { General assessment of the hydrological } \\
\text { cycle }\end{array}$} & 31 & 31 & 31 & 31 \\
\hline
\end{tabular}

Exceptionallywet: EH Exceptionallydry: ES Very wet: TH Very dry: TS Fairly wet: MH Fairly dry: MS Wet: H dry: S
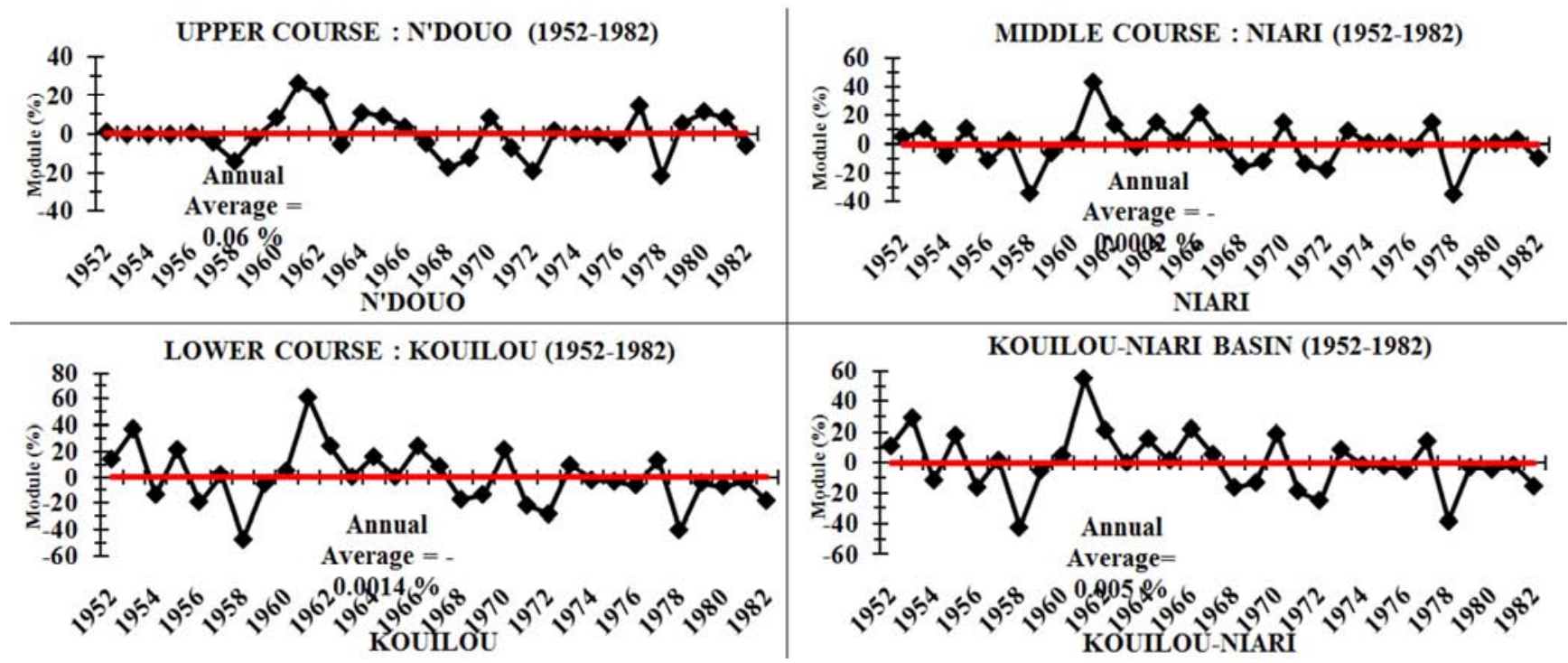

Figure 4. Evolution of Hydroclimatology (14)in the three courses of the Kouilou-Niari Basin.

These hydrological zones were not spared by the dryness for which the hardest years were 1958 and 1978. The year 1958 was declared very dry in Niari zone atBiyamba 1 station, while the year 1961 was declared exceptionally wet in Kouilou zone and very wet in the whole of the basin. There are also some moderately wet and moderately dry years, similarly there are some very dry years (Table 3). Years 1958, 1978 and 1961 are very remarkables, respectively for their dryness and their humidity observed in almost all the stations of the basin. This confirms the assumption of a fall of the flows in the Kouilou-Niari basin according to the precipitation. 


\subsubsection{Determination of the Various Classes of Streamflows}

The classification of the various classes of the streamflows according to the time gives two periods: a wet period and a dry period depending on humidity level (Table 2). Within each period, the years are divided in four groups: wet years, moderately wet years, very wet years, and exceptionally wet years. It is the same for the dry period. The analysis of the wet periods in the whole of the basin shows that the year 1961 was exceptionally wet, on the other hand, the year 1958 was very dry. There are more dry years than wet ones, respectively 17 and 14 years (Table 3 and Figure 4).

\subsection{Hydrological Assessment}

The Kouilou-Niari basin ismainly covered by the ombrophilous forest, it is sufficiently rainy $(1,604 \mathrm{~mm}$ of precipitation). Its deficit of flow is $709 \mathrm{~mm}$, with a specific module of $16.91 \mathrm{l} / \mathrm{s} / \mathrm{km}^{2}$, at the discharge system of the catchment area at Sounda station in Kouilouzone. This basin flows on a substratum which isvery little permeable to water. This explains its main hydrological characteristics (Tables $4 \& 5)$. The infiltration of rainwater into the soil is difficult, this explains a value of the runoff of $533 \mathrm{~mm}$ and a streamflow of $2,682 \mathrm{~m}^{3} / \mathrm{s}$ for a specific streamflow of 48.8 $\mathrm{l} / \mathrm{s} / \mathrm{km}^{2}$ (May 1953). This one becomes the first major flood of the hydrological cycle studied before the second observed (Mars 1961) with a streamflow of $2,620 \mathrm{~m}^{3} / \mathrm{s}$ and a specific streamflow of $47.60 \mathrm{l} / \mathrm{s} / \mathrm{km}^{2}$ at Sounda station. The minor low water levels wereobserved respectively at Loudima (September 1958) and Biyamba 1 (September 1978) stations with respective streamflows of $8 \mathrm{~m}^{3} / \mathrm{s}$ and $7 \mathrm{~m}^{3} / \mathrm{s}$ and specific streamflows of $2.06 \mathrm{l} / \mathrm{s} / \mathrm{km}^{2}$ and $3.74 \mathrm{l} / \mathrm{s} / \mathrm{km}^{2}$.

Table 4. Hydrological assessment of the Kouilou-Niari Basin (1952-1982).

\begin{tabular}{|c|c|c|c|c|c|c|c|c|c|}
\hline \multirow{2}{*}{ River } & \multirow{2}{*}{ Station } & \multirow{2}{*}{ Periode } & \multirow{2}{*}{$\begin{array}{l}\mathbf{N} \\
\text { (years) }\end{array}$} & \multirow{2}{*}{$\begin{array}{l}S \\
\left(K m^{2}\right)\end{array}$} & \multirow{2}{*}{$\begin{array}{l}\text { HP } \\
(\mathrm{mm})\end{array}$} & \multicolumn{4}{|c|}{ INTERANNUAL MODULE } \\
\hline & & & & & & $Q\left(\mathrm{~m}^{3} / \mathrm{s}\right)$ & Qsp (1/s/Km $\left.{ }^{2}\right)$ & $V\left(m^{\left.3 * 10^{\wedge} 7\right)}\right.$ & K3 \\
\hline N'douo & Moukomo & 1960-1982 & 23 & 3380 & 1371 & 80 & 23.73 & 253 & 8.8 \\
\hline Mpoukou & Lekana & $1957-1982$ & 26 & 3910 & 1549 & 92 & 23.58 & 291 & 6.0 \\
\hline \multirow{2}{*}{ Bouenza } & Makaka & $1962-1982$ & 21 & 4200 & 1297 & 101 & 23.95 & 317 & 5.4 \\
\hline & Bac miambou & 1952-1982 & 31 & 4920 & 1297 & 109 & 22.07 & 342 & 18.2 \\
\hline \multirow{3}{*}{ Niari } & Bac De la safel & $1956-1982$ & 27 & 8620 & 1116 & 170 & 19.73 & 536 & 14.4 \\
\hline & Kayes & 1953-1982 & 30 & 17190 & 983 & 332 & 19.33 & 1048 & 11.5 \\
\hline & Loudima & $1958-1982$ & 25 & 23385 & 1197 & 385 & 16.48 & 1215 & 11.2 \\
\hline Loudima & Loudima & $1955-1982$ & 28 & 3990 & 866 & 31 & 7.84 & 99 & 14.1 \\
\hline \multirow{2}{*}{ Louesse } & Biyamba 1 & $1957-1982$ & 26 & 1950 & 1604 & 59 & 30.41 & 187 & 20.0 \\
\hline & Makabana & $1959-1982$ & 24 & 15630 & 1289 & 306 & 19.58 & 965 & 10.4 \\
\hline Niari & Kibangou & $1952-1982$ & 31 & 48990 & 1548 & 847 & 17.29 & 2670 & 20.8 \\
\hline Kouilou & Sounda & $1952-1982$ & 31 & 55010 & 1242 & 930 & 16.91 & 2934 & 13.3 \\
\hline \multicolumn{2}{|c|}{ Kouilou-niari basin } & $1952-1982$ & 31 & 60000 & 1328 & 930 & 15.5 & 2933 & 10.9 \\
\hline
\end{tabular}

Table 4. Continued.

\begin{tabular}{|c|c|c|c|c|c|c|c|c|c|c|}
\hline \multirow{2}{*}{ River } & \multirow{2}{*}{ Station } & \multirow{2}{*}{ Periode } & \multirow{2}{*}{$\begin{array}{l}\text { De } \\
(\mathrm{mm})\end{array}$} & \multirow{2}{*}{$\begin{array}{l}\text { He } \\
(\mathbf{m m})\end{array}$} & \multirow{2}{*}{$\begin{array}{l}\mathrm{Ke} \\
(\%)\end{array}$} & \multirow{2}{*}{$\begin{array}{l}\text { Le } \\
(\mathrm{mm})\end{array}$} & \multicolumn{2}{|c|}{ Low water } & \multicolumn{2}{|l|}{ Flood } \\
\hline & & & & & & & $Q\left(\mathrm{~m}^{3} / \mathrm{s}\right)$ & $\operatorname{Qsp}\left(\mathbf{l} / \mathbf{s} / \mathbf{K m}^{2}\right)$ & $Q\left(\mathrm{~m}^{3} / \mathrm{s}\right)$ & Qsp $\left(\mathrm{l} / \mathrm{s} / \mathrm{Km}^{2}\right)$ \\
\hline N'douo & Moukomo & $1960-1982$ & 623 & 748 & 54.6 & 0.75 & 26 & 7.7 & 230 & 68.0 \\
\hline Mpoukou & Lekana & $1957-1982$ & 805 & 744 & 48.0 & 0.74 & 30 & 7.7 & 200 & 51.2 \\
\hline \multirow{2}{*}{ Bouenza } & Makaka & $1962-1982$ & 542 & 755 & 58.2 & 0.75 & 35 & 8.4 & 230 & 54.8 \\
\hline & Bac miambou & $1952-1982$ & 601 & 696 & 53.7 & 0.70 & 40 & 8.2 & 730 & 148.4 \\
\hline \multirow{3}{*}{ Niari } & Bac De la safel & 1956-1982 & 494 & 622 & 55.8 & 0.62 & 33 & 3.8 & 475 & 55.1 \\
\hline & Kayes & $1953-1982$ & 373 & 610 & 62.0 & 0.61 & 82 & 4.8 & 945 & 55.0 \\
\hline & Loudima & $1958-1982$ & 677 & 520 & 43.4 & 0.52 & 88 & 3.8 & 994 & 42.5 \\
\hline Loudima & Loudima & $1955-1982$ & 619 & 247 & 28.6 & 0.25 & 8 & 2.0 & 113 & 28.3 \\
\hline \multirow{2}{*}{ Louesse } & Biyamba 1 & $1957-1982$ & 645 & 959 & 59.8 & 0.96 & 7 & 3.7 & 146 & 74.9 \\
\hline & Makabana & 1959-1982 & 671 & 618 & 47.9 & 0.62 & 73 & 4.7 & 763 & 48.8 \\
\hline Niari & Kibangou & $1952-1982$ & 1003 & 545 & 35.2 & 0.54 & 115 & 2.3 & 2397 & 48.9 \\
\hline Kouilou & Sounda & $1952-1982$ & 709 & 533 & 42.9 & 0.53 & 201 & 3.7 & 2682 & 48.8 \\
\hline \multicolumn{2}{|c|}{ Kouilou-niari basin } & $1952-1982$ & 839 & 489 & 36.8 & 0.49 & 102 & 1.7 & 1109 & 18.5 \\
\hline
\end{tabular}

Specific Qsp $=$ streamflow in $1 / \mathrm{s} / \mathrm{Km}^{2}=\mathrm{Q}^{*} 1000 / \mathrm{S}$

$\mathrm{S}=$ Surface in $\mathrm{km}^{2}$

$\mathrm{V}=$ Volume run out in $\mathrm{m}^{3}=\mathrm{Q} * 3600 * 24 * 365$

$\mathrm{K} 3=$ Coefficient of Irregularity $=(\mathrm{Qmax} / \mathrm{Qini})$

$\mathrm{N}=$ years numbres
$\mathrm{HP}=$ average Precipitation in $\mathrm{mm}$

$\mathrm{De}=$ deficit of flow in $\mathrm{mm}=\mathrm{HP}-\mathrm{He}$

$\mathrm{Le}=$ equivalent water $(\mathrm{mm})=\mathrm{Q}^{*}=\mathrm{Q} * 31,5 / \mathrm{S}=\mathrm{Q} s \mathrm{p} * 31,5 / 1000$

$\mathrm{He}=$ Draining water $(\mathrm{mm})=\mathrm{Q} * 86,4 * 365 / \mathrm{S}$

$\mathrm{Ke}=$ Coefficient of flow in $\%=(\mathrm{He} / \mathrm{HP}) * 100$ 
Table 5. Monthly average streamflows (m3/s) of the stations in the Kouilou-Niari Basin (1952-1982).

\begin{tabular}{|c|c|c|c|c|c|c|c|c|c|c|c|}
\hline Basin & Uder-basin & River & Station & January & February & March & April & May & June & July & August \\
\hline \multirow{11}{*}{$\begin{array}{l}\text { Kouilou- } \\
\text { Niari Basin }\end{array}$} & \multirow{4}{*}{$\begin{array}{l}\text { Upper Course } \\
\text { (N'douo) }\end{array}$} & N'douo & Moukomo & 100.0 & 94.4 & 97.0 & 119.4 & 123.3 & 62.5 & 45.5 & 37.8 \\
\hline & & Mpoukou & Lekana & 106.0 & 109.9 & 117.5 & 137.1 & 137.4 & 79.0 & 56.5 & 45.4 \\
\hline & & \multirow{2}{*}{ Bouenza } & Bac miambou & 135.2 & 133.8 & 143.8 & 163.8 & 105.1 & 116.5 & 70.0 & 59.5 \\
\hline & & & Kibangou & 1018.6 & 1063.8 & 1180.9 & 1339.0 & 1269.8 & 640.7 & 443.6 & 357.3 \\
\hline & \multirow{6}{*}{$\begin{array}{l}\text { Middle Course } \\
\text { (Niari) }\end{array}$} & \multirow{3}{*}{ Niari } & Kayes & 430.7 & 414.8 & 436.3 & 521.1 & 512.3 & 242.8 & 162.6 & 129.6 \\
\hline & & & Loudima & 441.4 & 434.2 & 459.0 & 531.8 & 518.3 & 249.3 & 178.1 & 140.9 \\
\hline & & & Bac safel & 233.1 & 215.9 & 220.5 & 273.7 & 256.9 & 109.0 & 73.2 & 55.2 \\
\hline & & Loudima & loudima & 493.2 & 484.6 & 514.3 & 599.5 & 585.7 & 274.0 & 192.2 & 151.9 \\
\hline & & \multirow{2}{*}{ Louéssé } & Biyamba 1 & 71.3 & 73.5 & 79.2 & 87.0 & 84.8 & 47.6 & 30.8 & 22.3 \\
\hline & & & Makabana & 357.6 & 392.4 & 407.5 & 468.3 & 419.3 & 245.4 & 178.9 & 141.4 \\
\hline & Lower Course (Kouilou) & Kouilou & Sounda & 1120.3 & 1165.7 & 1299.7 & 1466.5 & 1457.8 & 727.8 & 485.8 & 382.7 \\
\hline
\end{tabular}

Table 5. Continue.

\begin{tabular}{|c|c|c|c|c|c|c|c|c|c|c|}
\hline Basin & Uder-basin & River & Station & September & October & November & December & Average & $\begin{array}{l}\text { Standard } \\
\text { deviation }\end{array}$ & Cv (\%) \\
\hline \multirow{11}{*}{$\begin{array}{l}\text { Kouilou- } \\
\text { Niari Basin }\end{array}$} & \multirow{5}{*}{$\begin{array}{l}\text { Upper Course } \\
\text { (N'douo) }\end{array}$} & N'douo & Moukomo & 35.7 & 48.5 & 90.6 & 108.1 & 80.2 & 32.3 & 40.2 \\
\hline & & Mpoukou & Lekana & 41.0 & 51.2 & 104.5 & 121.5 & 92.2 & 35.9 & 38.9 \\
\hline & & \multirow{3}{*}{ Bouenza } & Makaka & 51.0 & 58.8 & 108.5 & 127.7 & 100.6 & 35.5 & 35.3 \\
\hline & & & Bac miambou & 54.6 & 62.9 & 114.5 & 142.8 & 108.6 & 37.9 & 34.9 \\
\hline & & & Kibangou & 325.8 & 395.4 & 944.1 & 1183.0 & 846.8 & 387.5 & 45.8 \\
\hline & \multirow{5}{*}{$\begin{array}{l}\text { Middle Course } \\
\text { (Niari) }\end{array}$} & \multirow{2}{*}{ Niari } & Loudima & 124.9 & 155.6 & 394.9 & 521.0 & 345.8 & 162.8 & 47.1 \\
\hline & & & Bac safel & 48.9 & 68.7 & 212.5 & 274.2 & 170.1 & 90.9 & 53.4 \\
\hline & & Loudima & loudima & 133.2 & 166.6 & 442.3 & 586.3 & 385.3 & 186.7 & 48.5 \\
\hline & & \multirow{2}{*}{ Louéssé } & Biyamba 1 & 20.1 & 38.1 & 77.8 & 81.1 & 59.5 & 25.7 & 43.3 \\
\hline & & & Makabana & 129.7 & 156.5 & 374.6 & 401.6 & 306.1 & 125.7 & 41.1 \\
\hline & Lower Course(Kouilou) & Kouilou & Sounda & 331.1 & 401.4 & 1030.1 & 1295.7 & 930.4 & 438.4 & 47.1 \\
\hline
\end{tabular}

*The average streamflow of the Kouilou-Niari Basin is given in the lower course: Kouilou with Kakam

\subsection{Hydrological Classification}

The regional identification of each station and their differentiation previously established on the basis of physiographical and climatic criteria, must be examined for their hydrological functioning. To do that, two hydrologicalparameters which do not present physical links between them but which illustrate well the characteristics of their hydrological modesare compared. It is about the coefficient of flow and the coefficient of seasonal irregularity of the flows. Each river of the basin is represented by its main hydrometric station (Figure 5), according to two criteria and allows to constitute three sets of points.

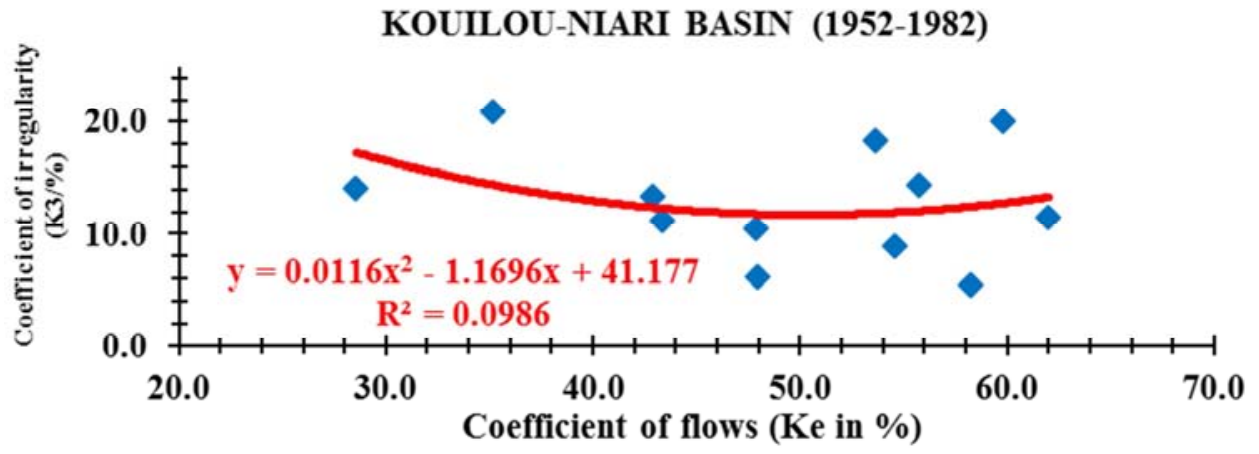

Figure 5. Hydrological classification of the various stations of the Kouilou-Niari Basin.

A first compact set of values corresponding to coefficients of flows ranging between 46.34 and 53.03 and coefficients of seasonal irregularity between 6.51 and 8.85 , a second group of points gathered at the center and less 
compact for which the coefficient of flow varies between 29.21 and 61.40 and the coefficient of seasonal irregularity between 10.44 and 14.39 and finally a third group of more dispersed points whose coefficient of flow varies between 35.31 and 59.49 and the coefficients of seasonal irregularity between 18.20 and 20.84, (Table 4 and Figure 5). The major point of the series is at the station of Kibangou with a coefficient of flow of 35.1 and a coefficient of seasonal irregularity of 20.84 .

\subsection{Statistical Approach of the Rainfall-Runoff Relation}

The coefficient of correlation is calculated using the rainfall and hydrometric data at monthly and interannual time step. The Figures 6 and 7 show the presence of as well monthly as interannualshitfts between rainfalls and runoffs: it is the response time between the rainfalls and the beginning of the flow. Indeed, season MAM concentrates about $35.21 \%$ of the total annual pluviometry. The distribution is extremely difficult, since it is marked by thepresence of the strong floods. In addition, season OND receives approximately
$37.65 \%$ of total pluviometry and other seasons JF and JJAS receive respectively only $24.35 \%$ and $2.79 \%$. The results of Table 6, show the presence of a considerable factor of worsening, because rainfalls of season OND which precede those of season MAM are used to saturate the soil and to recharge groundwater. The rains falling at the beginning of March find a soil with a weak rate of absorption. The flow is thus not instantaneous.

The analysis of the results gives as well monthly as interannual the comparison between the rainfall and hydrological modes and shows that streamflows are proportional to rainfalls (Figures. 6-7). Rainfall variability is expressed by the coefficients of variation (Table 5). In general, the stations of the Kouilou-Niari basin are marked by a strong spatialvariability (34.93 to $53.40 \%)$. The Kouilou-Niari basin as a whole has a coefficient of variation reaching $15.88 \%$. The lowest spatialvariability is recorded at Miambou station (34.93\%) and the stronger was obtained at Safel station $(53.40 \%)$. These values areclosedto those found by [28-29], which attest the weak spatial coherence.
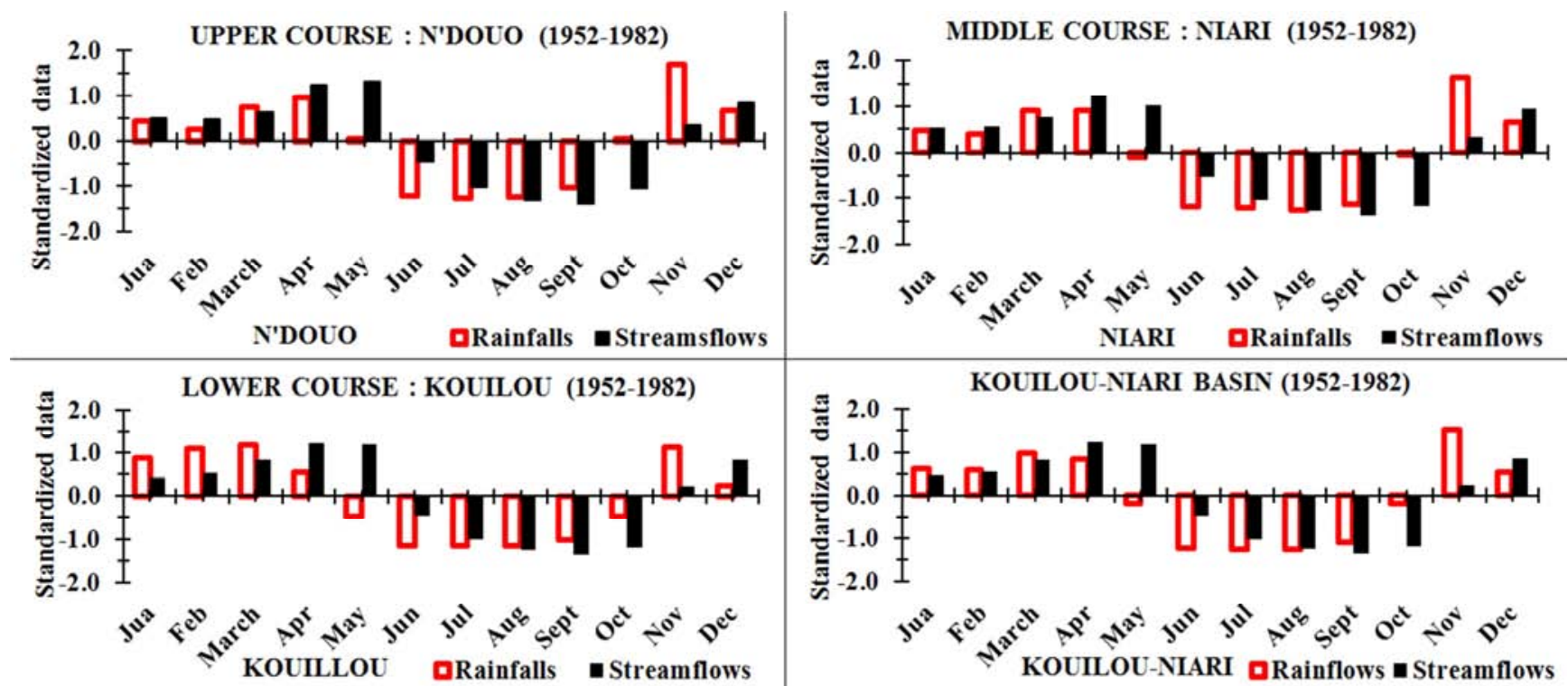

Figure 6. Monthly evolution of the pluviometric and hydrological modes of the three courses of the Kouilou-Niari Basin.

Table 6. Interseasonal evaluation of the average rainfalls and the flows at Sounda.

\begin{tabular}{|c|c|c|c|c|c|c|}
\hline Seasons Para & & JF & МАМ & JJAS & OND & Unity \\
\hline \multirow{5}{*}{$\begin{array}{l}\text { Flows } \\
\text { (streamflows) }\end{array}$} & Max & 1972 & 2289 & 743 & 1700 & \multirow{4}{*}{$\mathrm{m}^{3} / \mathrm{s}$} \\
\hline & Min & 621 & 562 & 269 & 566 & \\
\hline & Average & 1143 & 1408 & 482 & 909 & \\
\hline & Standard deviation & 254 & 394 & 117 & 237 & \\
\hline & $\mathrm{CV} \%$ & 22.22 & 27.96 & 24.35 & 26.11 & $\%$ \\
\hline \multirow{6}{*}{$\begin{array}{l}\text { Pluviometry } \\
\text { (rainfalls) }\end{array}$} & Sum & 11854 & 13097 & 562 & 12150 & \multirow{5}{*}{$\mathrm{mm}$} \\
\hline & Max & 737 & 679 & 65 & 885 & \\
\hline & Min & 40 & 37 & 4 & 63 & \\
\hline & Average & 382 & 422 & 18 & 392 & \\
\hline & Standard deviation & 166 & 168 & 14 & 244 & \\
\hline & $\mathrm{CV} \%$ & 43.41 & 39.85 & 77.54 & 57.31 & $\%$ \\
\hline
\end{tabular}




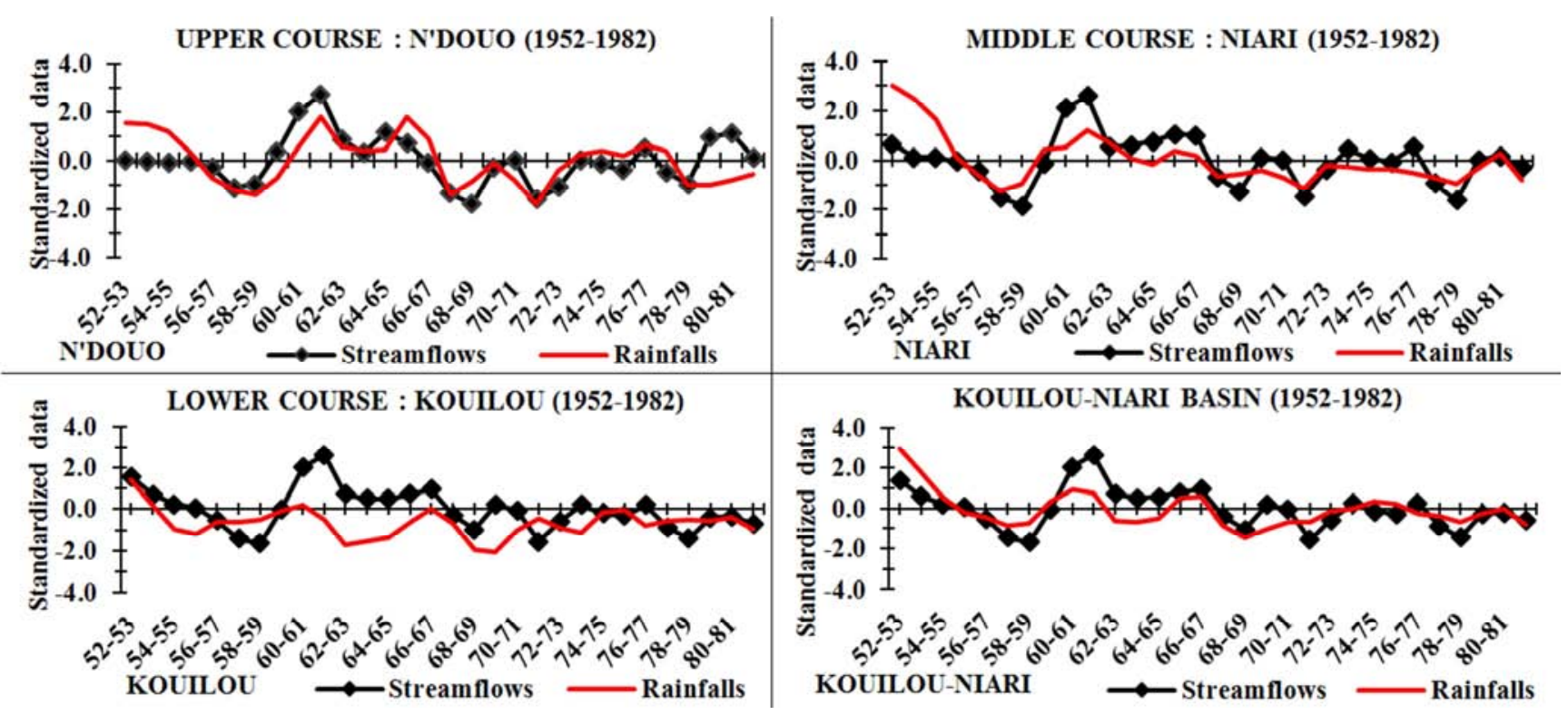

Figure 7. Interannualevolution of the pluviometric and hydrological modes of the three courses of the Kouilou-Niari Basin.

\subsection{Evolution of Pluviometries and Streamflows}

The study of streamflows and rainfalls in the Kouilou-Niari basin, makes it possible to highlight several major features of the evolution of the climate and its impact on the hydrological
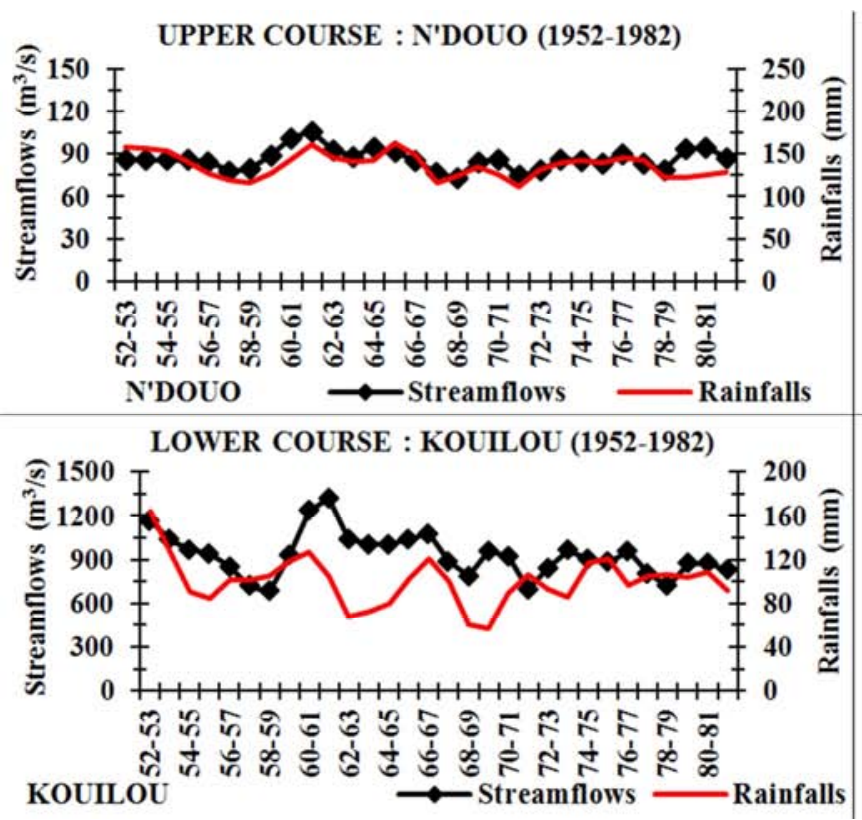

Figure 8. Interannualevolution of the rainfall / streamflow relation of the three courses of the Kouilou-Niari Basin.

The results obtained show the various variations between the two parameters rainfall and streamflow (Figure 8). The deficits of flows and rainfalls of the basin are proportionals. On the other hand the deficits of rainfalls are not enough extendedso that they havedurable effects on the hydrological modes andon the long-term water resources for a majority of the stations. If one is interested more finely in the distribution of rainfalls during seasons OND and MAM, one observes in certain cases some modifications which can be the origin of modes of the basin. In Congo, although it does not seem to have sustainable change of precipitation, the hydrological modes undergo sharpvariations, but short in time, and can also be more deeply disturbed at the seasonal level.

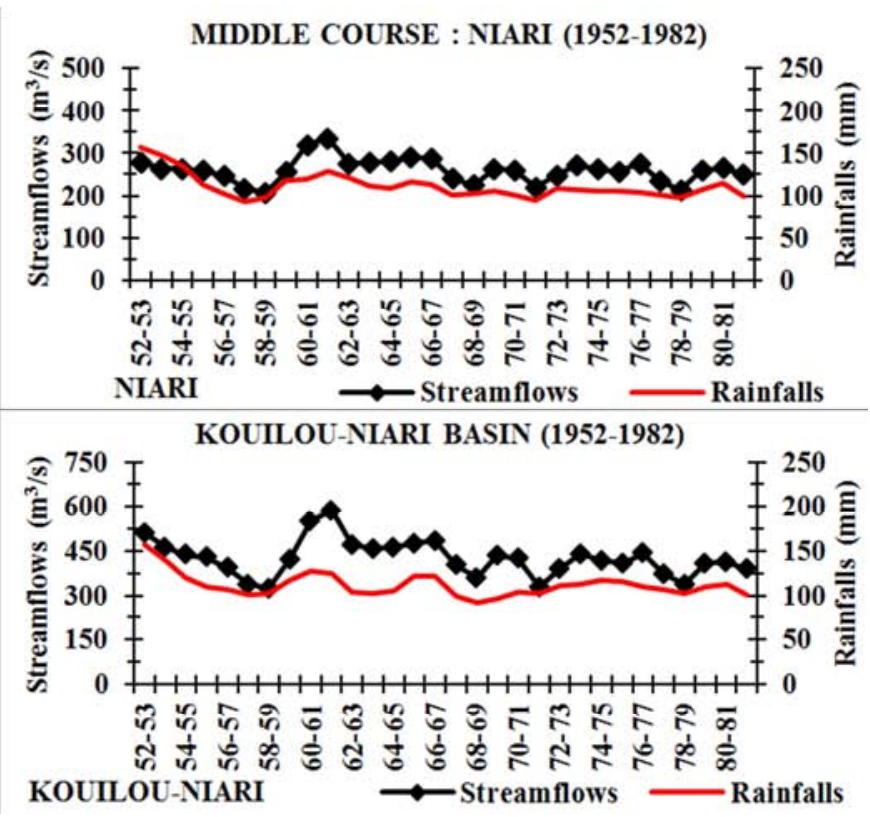

significant changes of hydrological modes of the basin, as show by [30], in a study on the equatorial zone.

\subsection{Rainfall-Runoff Relation}

The rainfall-runoff relation was established by the statistical method. The statistical study of streamflows and rainfalls highlights the correlation between the distinct variables rainfalls and runoffs, thanks to the linear regression of type $y=a x+b$. In this case, it is question to evaluate the 
streamflow using the precipitation measured in the various stations of the basin. For that, precipitation is represented by independent variable $\mathrm{X}_{\mathrm{i}}$ and streamflows by the dependent variable $Y_{i}$. The existence of any relation between the distinct variables depend on the value of the coefficient of correlation. The correlations between monthly and interannual precipitation and streamflowsare goods $(\mathrm{CR}=$ $61.73 \%)$. The examination of the curves of regression (polynomial model) of the defined hydrologicals zones (Figure 9), shows an enough well correlation in all the basin. The flows at the stations of basin are widely dependent on

UPPER COURSE : N'DOUO (1952-1982)

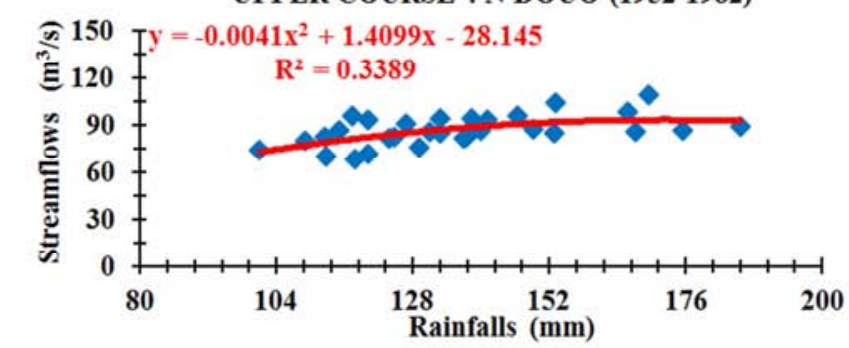

LOWER COURSE : KOUILOU (1952-1982)

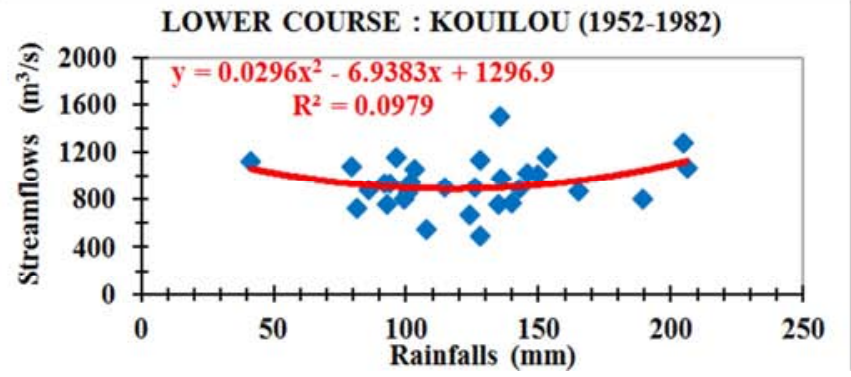

pluviometry, because the floods are feeded by the precipitation of seasons MAM and OND. The interannual evolution of the rainfall-runoff relation has been studied using annual averages of rainfalls and streamflows in the basin. The trend of evolution of flows shows that rainfalls and streamflows have evolved with the same variations in sinusoidal form during the hydrological cycle (1952-1982), with values included respectively between 61.6 and 205.5 $\mathrm{mm}$ and 683.8 and $1322.7 \mathrm{~m}^{3} / \mathrm{s}$, with a major peak $(1322.7$ $\mathrm{m}^{3} / \mathrm{s}$ ) between 1961 and 1962 (Figure 8).

MIDDLE COURSE : NIARI (1952-1982)

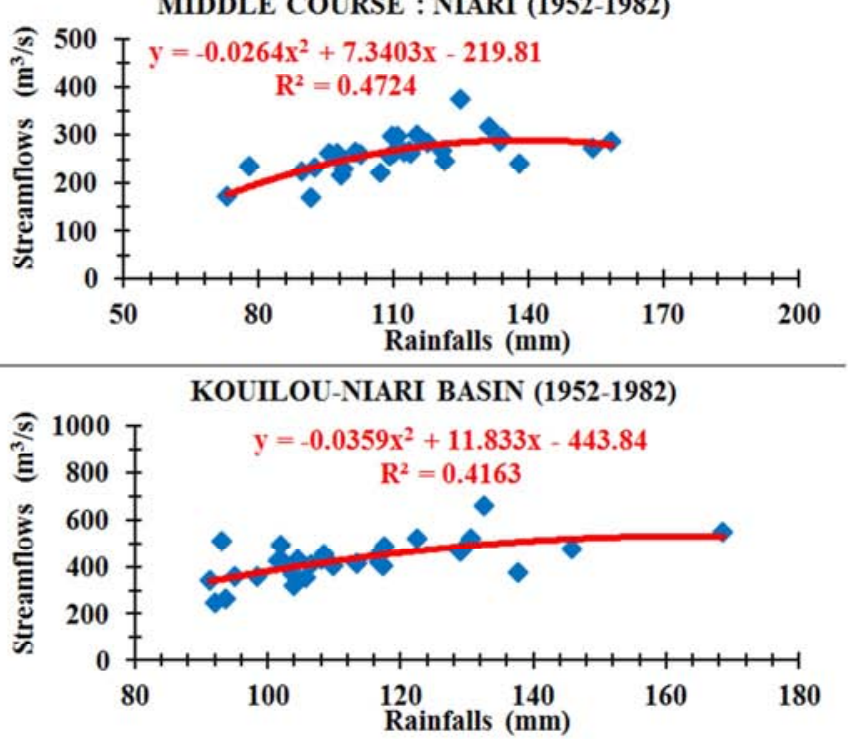

Figure 9. Evolution of the rainfall-runoff relation in the three courses of the Kouilou-Niari Basin.

The analysis of these flows shows a downward trend of streamflows compared to rainfalls in all the stations with slight differences. This observation was also made by [20, 31]. The trend of the interannual evolution of the flows is similar to that of precipitation. This rainfall-runoff relation confirms well that the streamflows of the stations of the Kouilou-Niari basin follow the rate of precipitation. Moreover, the interseasonal evolution of the rainfall-runoff relation has been studied using the sums of the annual averages of rainfalls and streamflows of the basin. The trend of the evolution of the flows shows that rainfalls and streamflows evolved proportionally and irregularly by forming peaks and troughs at the same moments, respectively during seasons MAM and JJAS of the

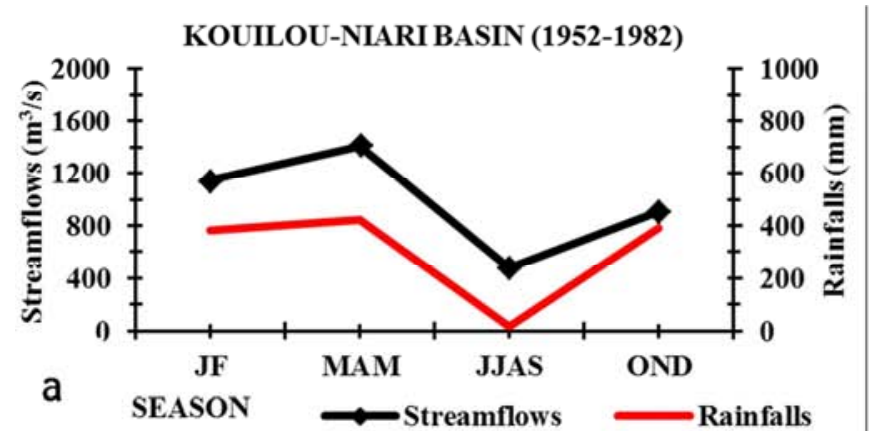

hydrological cycle (1952-1982), by fluctuating respectively between 30 and $468 \mathrm{~mm}$ and 891 and $1,909 \mathrm{~m}^{3} / \mathrm{s}$, and go up during season OND (10a). On the other hand, the analysis of the flows and rainfalls, per hydrological units, shows an upward trend of streamflows from N'douo zone to Kouilou zone by passing through Niari zone, and a downward trend of rainfalls, describing a concave curve. The rains fall from 136 to $111 \mathrm{~mm}$ and go up gradually to $123 \mathrm{~mm}$ in Kouilou. The trend of the evolution of the streamflows is not similar to that of precipitation (10b). This rainfall-runoff relation confirms well that streamflows evolve by increasing from one station to another, while rainfalls evolve by decreasing in all stations of the Kouilou-Niari basin.

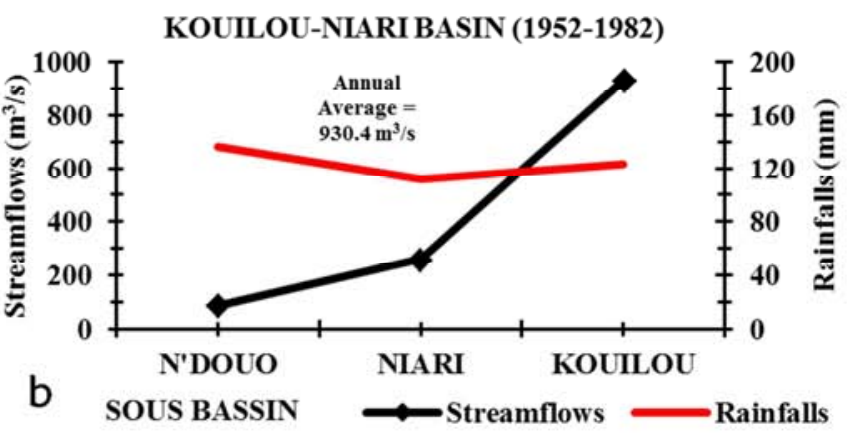

Figure 10. Seasonal evolution of streamlows and rainfalls in the Kouilou-Niari Basin. 


\section{Discussion of the Results}

The results obtained in this study were possible only after a detailed study of two main parameters (rainfalls and streamflows) and by subdividing the catchment area in three hydrological zones as indicated above. The study was primarily carried out on the behavior of the flows with respect to precipitation in the stations of the Kouilou-Niari catchment area. The charts show their evolutions according to the hydrological cycle.

\subsection{Evolution of Precipitation}

Three zones of rainfall evolution in the basin are distinguishables on both sides of a northeastern to southwest directed axis. On the northeastern part of this axis, average precipitation decreases and increases towards the southwest part of the axis (Figure 10b). In the upper course (N'douo), the pluviometry in deficit observed during the period 19551961 seems to be maintained and deteriorateslater by fluctuating between-22.12 and $26.18 \%$ (Figure 4). On the contrary, in the middle course (Niari), located at the center of the basin, the pluviometry is in surplus with proportions fluctuating between -35.45 and $44.18 \%$ and finally, the lower course (Kouilou) has pluviometry in surplus and satisfactory fluctuating between- 47.10 and $61.15 \%$. It follows from this analysis that, Kouilou zone presents favourable condition making it possible to carry out a future study on the modeling of the rainfall-runoff relation of the Kouilou-Niari basin, as made by [5] in their study on the catchment area of zoSassandra (Western of the Ivory-Coast) which suggests an upward trend of the monthly flows. As a whole, the KouilouNiari basin presents the following proportions of precipitation fluctuating between -43.89 and $55.83 \%$. The seasonal variations of precipitation on the whole of the basin, show that rainy seasons MAM and OND contain about $67.04 \%$ of the pluviometry of the basin against $32.96 \%$ for seasons JF and JJAS (Figure 10a). The major differences observed for the falls of annual average precipitation are explained by the reduction in the volumes of rainfalls between June and September. In general, the reduction of precipitation predict a possible reduction of the flows for the decades to come.

\subsection{Evolution of Streamflows}

For each hydrological zone of the catchment area, the graphs of monthly and annual precipitation built using the climatic data, are used to evaluate the impacts of the climate on the hydrological network of the basin. One supposes that rainfalls and streamflows remain the basic parameters for the hydrological modeling of the basin. The values of streamflows thus simulated can be regarded as realistic values making it possible to lead to good orders of magnitude. This values have been compared with the observations to evaluate the modifications in terms of rate of variations. In general, the impact of the climate change on the flows varies according to the precipitation projected by the hydrological model. It seems that the continuous variation of flows related to that of precipitation, doesn't affect much the hydrological balance. The trend of the flows is toward the fall in N'douo zone. The charts (Figure 4), show that the annual average deficits fluctuate between -22 and $26 \%$. On the contrary, in Niari zone the annual average deficits simulated in the last decades of the cycle 1952-1982, vary between -35 and $44 \%$. Finally, Kouilou zone presents surplus and satisfactory conditions ranging between -47 and $61 \%$. However, climatic projections (Figure 4) predict a fall of the flows in the decades to come. But, the flows do not seem to find the levels observed before the dryness which sufferedcentral and western Africa in the years 1950 [32]. This prediction seems contrary with that envisaged by [3] at the end of this century in two rivers in Ethiopia and by [2] in the Jing river in China.

To sum up, the variations observed on the flows result in those of volumes of rainfalls into the basin. The comparison of the annual average hydrograph of the three courses to that of the Kouilou-Niari basin, shows that there are not too many modifications on the hydrological mode from one course to another. The minimum of streamflows have been recordedin September withrates of reduction of $-21.67 \%$ in N'douo, $34.96 \%$ in Niari and $-47.36 \%$ in Kouilou. The Kouilou-Niari basin presents a reduction of the flows between June and September of about $-43.53 \%$. One observes a light shift of peak of floods accompanied by a light increase of streamflows. The peak of streamflows is recorded in May with an increase of $+14 \%$ compared to the streamflow of reference observed in September in Kouilou, in the reference period 1952-1982. Preceding studies have shown that the central Africa is characterized by a poor space structuring of precipitation [32]. The variability of rainfalls with monthly time step is not much documented, particularly in Republic of Congo. Indeed, there are not much informations on the structuring of rainfalls on dayly, monthly and annual scales. The reduction of precipitation in most of the basin implies really unstable climatic conditions with the passing of the years, or on the contrary a strong interannual variability masked by the high average level of precipitation.

\section{Conclusion}

The objective of this study was to evaluate the impacts of the evolution of the trend of precipitation on the streamflows in the Kouilou-Niari basin. The results obtained made it possible to confirm the persistence of a mode of precipitation of the bimodal type in the basin with two rainy seasons (OND and MAM) and two dry seasons (JF and JJAS). Annual and seasonal average precipitation unequally vary from the north to the south of the basin. The basin undergoesa deep changes mainly characterized by a generalized reduction of rainfalls. This reduction leads in the majority of the cases to reduction of the flows. The evolution of precipitation of the basin shows at the same time a great variability and an absence marked by a fall, where as the 
streamflows are exceptionally highs at the beginning of the years 1960 .

This study proposes, in addition, a methodology allowing to evaluate the potential impacts of the climate change on the hydrological network of the Kouilou-Niari basin, based on projections of hydrological modeling. The variations will increase from the years 2030 with appearance of the optimum floods (Figure 10): rise in temperature and thus in potential evapotranspiration(ETP)associated with a reduction (northeastern area) and with an increase (southwestern area) of precipitation and thus of the flows. It would be interesting to study the seasonal variability of the rainfall pattern, as in [3] where the authors suggest that in the dry season, rainfall amounts are likely to increase and in the wet season rainfall amounts are likely to decrease. Simulations of the flows of the basin during the $21^{\text {st }}$ century will depend primarily on the hydrological model used but also on climatic projections. The results obtained will make it possible to realize on the one hand, hydrological modeling using a multidimensional variable model being able to manage several parameters; and on the other hand, the modeling of the rainfall-runoff relation using a numerical model (for example the GR2M). This model could take into account the climatological parameters (precipitation, temperature, relative humidity, evaporation, etc.), the conditions of flows, the geology of the medium and the exchanges between different aquifers.

Ultimately, the Kouilou-Niari basin like equatorial Africa, although it does not seem to have sustainable change of precipitation, the hydrological modes know sharp variations, but the short ones in time. In prospects, thorough studies on the flows must be carried out in the Kouilou-Niari basin, with a more significant data. In addition, it would be necessary to develop experiments of measurement on sahelian and Congolese basins in order to better appreciate these variations or these impacts of the climate change on the water resources of the catchment area of Kouilou-Niari.

\section{Acknowledgements}

We would like to thank Mr Jacques Ngoulou for his remarks and observations.

\section{References}

[1] Salami A W, Ibrahim H and OlatunbosunSojobi A. Evaluation of impact of climate variability on water resources and yield capacity of selected reservoirs in the north centralNigeria. Environ. Eng. Res. 2015, 20 (3), 290-297. http://dx.doi.org/10.4491/eer.2015.0041.

[2] LiZ and Jin J. Evaluating climate change impacts on streamflow variability basedon a multisite multivariate GCM downscaling method in the Jing River of China. Hydrol. EarthSyst. Sci. 2017, 21, 5531-5546. https://doi.org/10.5194/hess-21-5531-2017.

[3] Worqlul, A. W, Dile, Y. T, Ayana E K, Jeong J, Adem A A and Gerik T. Impact of Climate Change on Streamflow Hydrology in Headwater Catchments of the Upper Blue NileBasin,
Ethiopia. Water, 2018, 10, 120, 1-18, doi:10.3390/w10020120

[4] Teutschbein, C and Seibert J. Bias correction of regional climate model simulations for hydrological climate-change impact studie: Review and evaluation of different methods, J Hydrol, 2012， 12-29，456-457, doi:10.1016/j.jhydrol. 2012.05.052.

[5] Kouamé K F, Kouassi A M, N'guessan B T M, Kouao J M, Lasm T and Saley M B. Analysis of trends in the rainfallrunoff relation in the context of climate change: case of the N'zo-Sassandra watershed (Western Côte d'Ivoire). International Journal of Innovation and Applied Studies. 2013, 2(2), 92-103. http://www.issr-journals.org/ijias/.

[6] Aykut S C and Dahan A. Le régime climatique avant et après Copenhague:sciences, politiques et l'objectif des deux degrés. Natures Sciences Sociétés. 2011, 19, 144-157. DOI: $10.1051 / \mathrm{nss} / 2011144$. (in french)

[7] Thierry B. Climate change impacts and food securi:lessons from the IPCC fifth assessmentreport. AgronomieEnvironementetsociétés. 2015， 5(1), 13-22. (infrench).

[8] Camberlin P. L'Afrique Centrale dans le contexte de la variabilité climatique tropicale interannuelle et intrasaisonnière. CNRS UMR 5210, université de Bourgogne, $14 \mathrm{p}, 2010$. (in french).

[9] Servat E., Paturel J. E., Kouame B., Travaglio M., Ouedraogo M., Boyer J. F., Lubes-Niel H., Fritsch J. M., Masson J. M., Marieu B., 1998: Identification, caractérisation et conséquences d'une variabilité hydrologique en Afrique de l'Ouest et centrale. IAHS Publication, n²52, pp.323-337.

[10] Ardoin, S., Lubës-Niel, H., Servat, E., Dezetter, A., Boyer, J. F., Mahè, G. \& Paturel, J. E., 2003: Analyse de la persistance de la sècheresse en Afrique de l'Ouest: Caractérisation de la situation de la décennie 1990. In: Hydrology in the Mediterranean and Semiarid Regions (ed. by E. Servat, W. Najem, C. Leduc \& S. Ahmed) (Proc. Montpellier Conf., April 2003), 223 ñ 228. IAHS Publ. 278, IAHS Press, Wallingford, UK.

[11] GIEC. 2007: Bilan 2007 des changements climatiques: Rapport de synthèse du Groupe d'experts intergouvernemental sur l'évolution du climat, publication. $\mathrm{n}^{\circ} 4,114 \mathrm{p}$.

[12] Tchicaya J. A., 1994: Etude Hydrogéologique du bassin du Kouilou-Niari. Mémoire de DEA de Géographie physique " systèmes spatiaux et aménagement régionaux »à l'Université LOUIS PASTEUR «centre d'étude et de recherches écogéographiques, France, 68p.

[13] PANLCD, 2006: Programme d'Action National de Lutte Contre la Désertification (Mars 2006), 57p.

[14] IbiassiMahoungou G., 2003: Les structures spatiales des précipitations saisonnières de I'Afrique Equatoriale Atlantique et leurs relations avec les températures de surface océanique de l'Atlantique Equatoriale de 1950 à 1993. Mémoire de D. E. A, de Géographie physique, Université Marien NGOUABI, Brazzaville; 140p.

[15] Energie Electrique d'AEF, Electricité de Franche-I. G. U. F. E. fleuve Kouilou-Niari, Amenagement de Sounda. Monograph fleuve Kouilou-Niari, Tome III, 63p, Fev1958.

[16] Rodier J. P., 1964: Régimes hydrologiques de l'Afrique noire à l'ouest du Congo. 
[17] Tardy Y., 1986: Le cycle de l'eau: climats, paléoclimats et géochimie globale. Edition Masson, Paris, 341p.

[18] Sneyers R., 1975: L'analyse statistique des séries d'observations Note technique ${ }^{\circ}$ 143, OMM, (415), 192p.

[19] Fontaine B., 1990: Champ Atlantique pluviométrique Ouest Africain et oscillation australe. Veille climatique satellitaire, n³2 pp34-50.

[20] Mahé, G., 1993: Les écoulements fluviaux de la façade atlantique de l'Afrique. Etude des éléments du bilan hydrique et variabilité interannuelle. Analyse des situations hydro climatiques moyennes et extrêmes. Coll. Etudes et Thèses. ORSTOM Paris, 438p.

[21] Mahé, G., Olivry, J. C., 1995: Variations des précipitations et des écoulements en Afrique de l'Ouest et centrale de 1951 à 1989. sécheresse 6 (1), 109-117. Mémoires ORSTOM 6, 137p.

[22] Bigot S., Camberlin P., Moron V., Richard Y., 1997: Structures spatiales de la variabilité des précipitations en Afrique: une transition climatique à la fin des années 1960, Comptes Rendus de l'Académiedes Sciences, série II, Sciences de la Terre et des Planètes, 324, série IIa, pp181-188.

[23] Bigot S., Brou Y. T., Oszwaid J., Diedhiou A., 2005: Facteurs de la variabilité pluviométrique en Côte d'Ivoire et relations avec certaines modifications environnementales. Sécheresse, vol. $16, \mathrm{n}^{\circ} 1, \mathrm{pp} .5-13$.

[24] Laraque A. et Olivry J. C., 1998: Deux systèmes hydrologiques mitoyens mais opposés du bassin Congo Zaïre: la Cuvette Congolaise et les plateaux téké, international conférence «tropical climatology, meteorology and hydrology» (Brussels, 22-24 May 1996) preceedingedited by G. Demarée. J, Alescandre and M. De Dapper pp593-606.
[25] Musy A., et Higy C., 2003: Collection gérer I'environnement. Hydrologie une science de la nature. presses polytechniques et universitaires romandes, Lausanne; $314 \mathrm{p}$.

[26] Cosandey C., Bigot S., Dacharry M., Gille E., Richard L., Salvador P. G., 2004: les eaux courantes, Saint Etienne, éditions Belin, 229p.

[27] Souad A., et Abderrahamn., 1999: Hydrologie et fluctuations hydro climatiques dans le bassin du Sebou entre 1940 et 1994. Sécheresse, n³, vol. 10, pp221-226.

[28] Batchi-Mav A., 2003: Variabilité pluviométrique au Sud du Congo (1950-1998), Mémoire de Maîtrise de Géographie, Université Marien NGOUABI, Brazzaville; 91p.

[29] Bigot S., 1997: Les précipitations et les convections profonde en Afrique centrale: Cycle saisonnier, variabilité interannuelle et impact sur la végétation. Thèse de Doctorat, Université de Bourgogne, Centre de recherches de Climatologie; 282p.

[30] Mahé, G., Olivry, J. C., 1991: Changements climatiques et variations des écoulements en Afrique occidentale et centrale du mensuel à l'interannuel. IASH Publ., 201, 163-172.

[31] Olivry J. C., 1993: Evolution récente des régimes hydrologiques des grands fleuves d'Afrique de I'ouest et centrale in les écosystèmes intertropicaux, fonctionnement et usage- journées du programme environnement CNRS ORSTOM, 13, 14, 15 janvier 1993, Lyon, 9p.

[32] Bigot S., Moron V., Michel J L., 1998: Water Resources Variability in Africa dun"ngIheXX ${ }^{\text {ième }}$ CenJury(proceedings of lhe Abidjan'98 Conference 71 held at Abidjan, Cote d'lvoire, November 1998). IAHS Pub. no. 252, 1998. 